$\xi=-1$

\title{
Treatment of Pretreated Textile Wastewater Using Modified Mbbr
}

\author{
K.J.Sosamony ${ }^{1 *}$,P.A.Soloman ${ }^{2}$ \\ ${ }^{1}$ Civil Engineering Dept., Govt. Engineering College Trichur, Kerala \\ ${ }^{2}$ Chemical Engineering Dept., Govt. Engineering College Trichur, Kerala \\ Corresponding author email: sosajava@ rediffmail.com
}

\begin{abstract}
Currently, water pollution control is one of the major logical zones. The textile industry is a major pollution causing industry among the industrial pollutions. Treatment of textile effluent utilizing customary physical as well as chemical strategies is costly, produces enormous amounts of sludge and needs the expansion of lethal chemicals. BOD to COD proportion of textile effluent is low. Thus it is not appropriate to treat textile effluent by a solitary physicochemical or biological process. In this investigation, the textile effluent is dealt with utilizing Moving Bed Bio-film Reactor (MBBR) with the magnetic field after improving the biodegradability by the solar photoFenton process. The carriers in MBBR is inoculated with azoarcus bacteria isolated from textile sludge. The fundamental parameters as $\mathrm{pH}$, carrier filling ratio and contact time were optimized utilizing Box Behnken factual design. The MBBR process has most extreme efficiency at $\mathrm{pH} 7$, filling ratio of $62 \%$ and a contact time 2.4 days. In this optimum condition $68.9 \%$ BOD and $80 \%$ COD are expelled. At the point when the pretreated wastewater was dealt with MBBR reactor under the influence of magnetic field, the efficiency of the treatment is additionally expanded, so $87.4 \%$ COD expulsion and $87 \%$ BOD evacuation were accomplished at 12 mT attractive field power when exposure time was at $12 \mathrm{hrs}$.
\end{abstract}

Keywords: Box Behnken factual design; magnetic field; MBBR; solar photofenton; textile effluent

\section{Introduction}

The textile industry is one of the best generators of fluid effluent toxins, because of the tremendous amounts of water utilized as a part of the dyeing processes. With the expanded interest for textile items, the textile industry and its wastewater have expanded relatively making it one of the fundamental sources of extreme pollution issues worldwide $(1,2,21,22)$. The effluent within the sight of wastefully treated dyestuff can cause tasteful and ecological issues in aquatic ecology interfering with biological digestion on the grounds that most dye materials are dangerous and conceivably carcinogenic $[3,7,20,27,28,30]$. Along these lines, a concentrated treatment is required for the textile effluent previous to its disposal. Execution of physical or chemical strategies alone makes the treatment exorbitant since it includes more energy utilization and chemicals employments. The biological treatment through microbial decolorization and debasement of dyes has been of extensive enthusiasm since it is cheap, eco-friendly, and delivers a less measure of sludge. The adequacy of microbial decolorization relies upon the versatility and the movement of chosen small scale organisms $[5,9,10,27]$.

The moving bed biofilm reactor (MBBR) is a very viable biological treatment process that has been created on the premise of conventional activated sludge and bio filter methods. The biomass in the MBBR exists in two structures: suspended flocs and a biofilm joined to transporters. This procedure depends on non-clogging biofilm reactor with no requirement for discharging, low headloss and a high particular biofilm surface zone. It is a totally blended and continuously operated biofilm reactor, where the biomass is developed on small carrier components that have a little lighter density than water and are kept in development alongside a water stream within the reactor. The development of a reactor can be caused by air circulation in an oxygen consuming reactor and by a mechanical stirrer in the reactor $[8,18,19,24,25]$.

The Design Expert Software Minitab adaptation 16 was utilized to design the number of examinations to be performed, evaluate the experimental information and assess the test outcomes. With a specific end goal to examine the impacts of critical factors and to get the optimal conditions in this examination, the Box-Behnken factual design was utilized. The enhancement methodology includes examining the reaction of actually outlined mix, evaluating the coefficients by fitting experimental data to the reaction capacities and foreseeing the reaction of fit model. [31]

Magnetic water treatment is generally new systems in natural administration with a considerable measure of utilizations, for example, scale avoidance/disposal, soil improvement, plant development, crop yield, water sparing, and wastewater treatment [11]. Magnetic field introduction adjusts physical as well as chemical properties of water particles bringing about extraordinary qualities. Past research center and field studies have demonstrated the high effectiveness of electromagnetic strengths as adjunctive or option treatment for traditional wastewater treatment $[12,13]$. The magnetic field application has a potential in affecting the biological properties through the change of bacterial movement. Magnetic application likewise enhances the physical properties of wastewater as far as strong fluid partition basically through a conglomeration of colloidal particles [12,13,14,15,16,17].

The textile wastewater has low biodegradability and the $\mathrm{BOD} / \mathrm{COD}$ proportion is around 0.2. In this manner to make it 
agreeable for MBBR process chemical pretreatment is done and $\mathrm{BOD} / \mathrm{COD}$ proportion is upgraded to 0.5 . The solar photo-Fenton treatment is picked as the pre-treatment since it permits a high rate of degradation at room temperature and pressure, simple to lead and in particular, the procedure uses the characteristic daylight as an energy source [29, 30].

In this work, the treatment of pretreated textile wastewater utilizing MBBR process and the impact of magnetic field on the treatment is examined. The impact of parameters like $\mathrm{pH}$, carrier filling ratio along with its contact time in the removal of BOD and COD from the wastewater by MBBR treatment is contemplated Likewise, MBBR is operated by the magnetic field to ponder the impact of field exposure time and field intensity. Finally, the maximum removal efficiency of BOD and COD is resolved under the optimized conditions.

\section{Materials and Methods}

\subsection{Sampling of Textile Wastewater}

The specimens of untreated real textile wastewater were gathered from Cannanore Handloom Exports Ltd, Kannur. The water prerequisite for the industry is 40 to $50 \mathrm{~m}^{3} /$ day and the dyeing procedure produces 20 to $30 \mathrm{~m}^{3}$ wastewater while preparing $200 \mathrm{~kg}$ cotton each day. The dyes mainly utilized by the industry are Ramazol Red F 3B, Olive R and Ramazol Turquoise blue CG. The wastewater samples are stored at $4^{\circ} \mathrm{C}$ and investigated to decide the attributes. Table 1 demonstrates the qualities of untreated real textile wastewater.

Table 1 characteristics of untreated textile wastewater

\begin{tabular}{ccc}
\multicolumn{2}{c}{ Table 1 characteristics of untreated textile wastewater } \\
\hline Parameter & concentration & Unit \\
\hline BOD & 210 & $\mathrm{mg} / \mathrm{L}$ \\
COD & 980 & $\mathrm{mg} / \mathrm{L}$ \\
pH & 12 & - \\
TDS & 970 & $\mathrm{mg} / \mathrm{L}$ \\
Alkalinity & 1200 & $\mathrm{mg} / \mathrm{L}$ \\
Chloride & 180 & $\mathrm{mg} / \mathrm{L}$ \\
Turbidity & 64 & $\mathrm{NTU}$ \\
Hardness & 140 & $\mathrm{mg} / \mathrm{L}$ \\
Sulphide & 44 & $\mathrm{mg} / \mathrm{L}$ \\
\hline
\end{tabular}

\subsection{Pretreatment Using Solar Photofenton}

The solar photo-Fenton treatment was given to the wastewater. $500 \mathrm{~mL}$ sample volume was taken. $\mathrm{pH}$ was balanced utilizing $\mathrm{H}_{2} \mathrm{SO}_{4}$ or $\mathrm{NaOH}$. At that point, iron salt $\left(\mathrm{FeSO}_{4} .7 \mathrm{H}_{2} \mathrm{O}\right)$ of required weight was included. It was blended well with wastewater for 10minutes. The trial setup was put under the sunlight and required volume of $\mathrm{H}_{2} \mathrm{O}_{2}$ was included. The response time begins with the mixing of $\mathrm{H}_{2} \mathrm{O}_{2}$ and the reagents were completely blended. The light intensity was measured utilizing a light meter. The solar photo-Fenton treatment was done at $\mathrm{pH} \mathrm{3}$, response time $30 \mathrm{~min}$., $\mathrm{Fe}^{2+} 4 \mathrm{mg} / \mathrm{L}$, and $20 \mathrm{mM} \mathrm{H} \mathrm{O}_{2}$. This trial was directed at solar intensity of $20 \mathrm{~W} / \mathrm{m}^{2}$ which was the most accessible solar power at the time of venture work. By this pretreatment, BOD: COD proportion increased from 0.21 to 0.54 .

\subsection{Moving Bed Biofilm Reactor (MBBR) Experiment}

A lab-scale reactor with a volume of $11.25 \mathrm{~L}$ is utilized to treat the wastewater. It is an acrylic glass reactor of size $15 \times 15 \mathrm{~cm}$ along with height $50 \mathrm{~cm}$. An aerator of limit $3 \mathrm{~L} / \mathrm{min}$. was joined to the base of the reactor for the air supply. Paddles made up of acrylic sheet fitted with a motor were additionally given in the middle to combine the carrier components with the wastewater. The paddles are pivoted at a speed of $30 \mathrm{rpm}$. The carrier elements for the MBBR process were PVC corrugated cylinders with internal diameter of $1.5 \mathrm{~cm}$, external diameter of $2 \mathrm{~cm}$ and height of $1.4 \mathrm{~cm}$. The carriers have a density of $0.94 \mathrm{~g} / \mathrm{cm}^{3}$ and specific surface area of $350 \mathrm{~m}^{2} / \mathrm{m}^{3}$

\subsection{Inoculation of Carrier Elements}

The sludge from air circulation tank of Cannanore Handloom Exports Ltd was collected to isolate the overwhelming bacterial species and brood the same to the carrier components. The ID and confinement of microscopic organisms were done in the Department of Microbiology, Kerala Agriculture University, Vellanikkara. The recognizable proof is finished by $16 \mathrm{~S}-\mathrm{rRNA}$ technique. The prevalent species was azoarcus. The colonies of azoarcus were isolated, transferred to peptone nutrient medium and permitted to develop and multiply for $24 \mathrm{hrs}$ at room temperature. At that point, the carriers are placed in the bacterial culture for $12 \mathrm{hrs}$. The transporters were air-dried and filled in the reactor. The Quadrant streaked culture of azoarcus microorganisms is appeared in fig. 1.

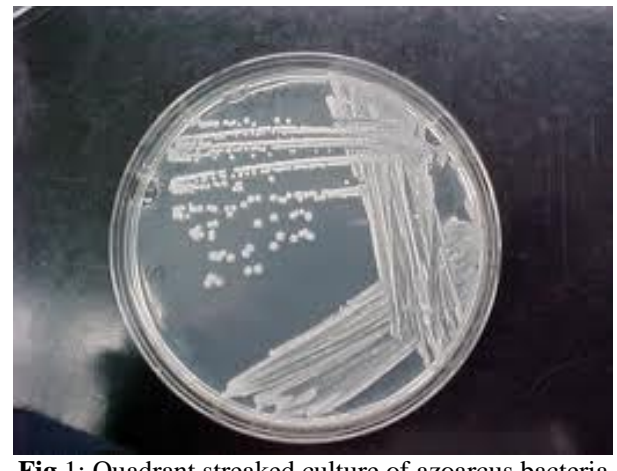

Fig.1: Quadrant streaked culture of azoarcus bacteria

\subsection{Experimental Design of MBBR}

Different components influencing treatment of textile wastewater in moving bed biofilm reactor are contact time, $\mathrm{pH}$ and filling proportion of carriers in the empty reactor. Optimization of differing parameters is finished by Box Behnken technique utilizing MINITAB programming. For $\mathrm{pH}$, the range is chosen from 6-9 which depends on past investigation. This $\mathrm{pH}$ range is reasonable for bacterial development. For filling ratio (FR), the range is 40$80 \%$ and the contact time received was in the range 1-3days.

\subsection{MBBR under Magnetic Field}

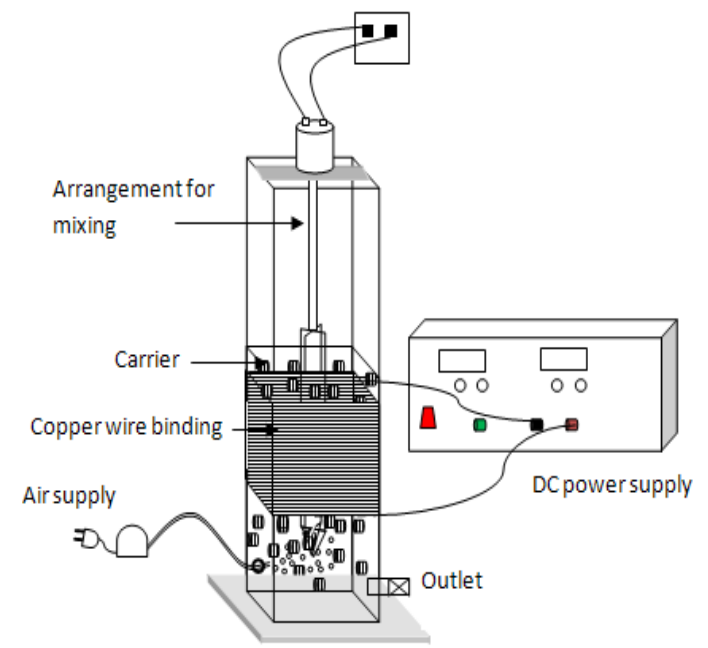

Fig. 2: Schematic diagram for MBBR with magnetic field

The magnetic field applied to the wastewater in the MBBR reactor to decide its impact on the procedure. Two reactors with arrangements for air circulation and blending were orchestrated so one act as a control (without magnetic field). Magnetic field is created by winding copper wires around the second reactor and passing DC current through it (Fig. 2).

The impact of the field on MBBR process is considered by fluctuating the field exposure time and field intensity. The two reactors 
were worked at a given $\mathrm{pH}$, filling ratio of carriers and contact time. The distinctive magnetic intensity ( 4 to $14 \mathrm{mT}$ ) is applied by altering the DC supply and for each run of the examination rate expulsion of BOD and COD are computed.

\section{Results and Discussions}

\subsection{Effect of Parameters on COD Removal}

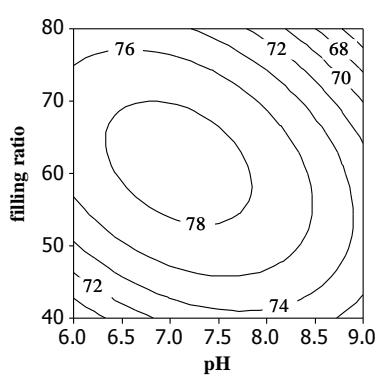

(b)

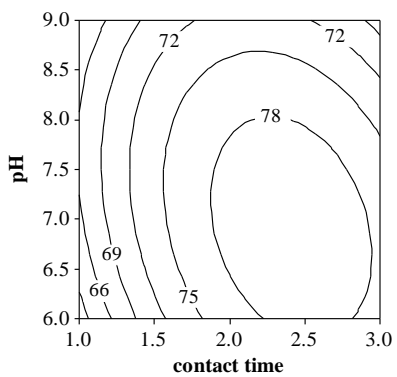

(c)

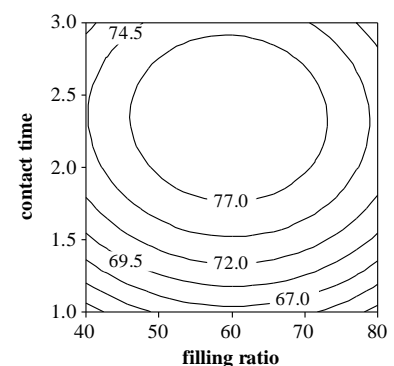

(a)
Fig.3: Contour plots of COD removal vs (a) $\mathrm{pH}$ and filling ratio at contact time 2 days, (b) filling ratio and contact time at $\mathrm{pH} 7.5$, (c) $\mathrm{pH}$ and contact time at filling ratio $60 \%$

The impact of parameters like contact time, $\mathrm{pH}$ and filling ratio on COD expulsion can be effortlessly translated from the contour plots given in figure 3 . As the contact time expands, COD removal increases and after that decreases and the most extreme removal is acquired when the time achieves 2.5 days. As filling ratio increases from $40-70 \%$, COD removal increases. When filling proportion increases to $80 \%$, efficiency diminishes. This is because when filling ratio is expanded over $70 \%$, there won't be appropriate mixing. When filling ratio is diminished below $40 \%$, oxygen exchange efficiency will be poor. Optimum $\mathrm{pH}$ is in the range 7.5-8.5 in light of the fact that bacterial development in MBBR is optimum in that $\mathrm{pH}$ range.

\subsection{Effect of Parameters on BOD Removal}

The contour plots of BOD removal appeared in figure 4 clarify the impact of every parameter simultaneously.

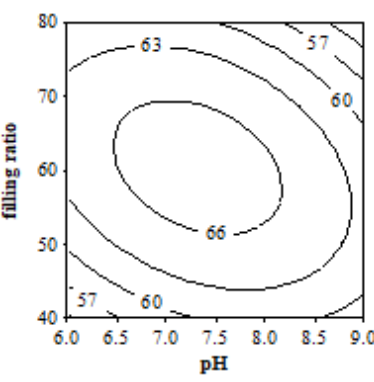

(a)

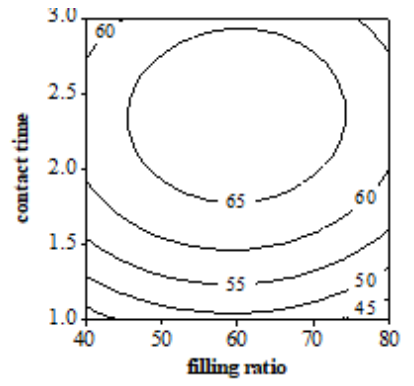

(b)

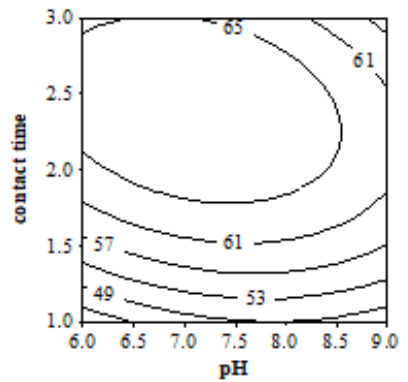

(c)

Fig.4: Contour plots of BOD removal vs (a) $\mathrm{pH}$ and filling ratio at contact time 2 days, (b) filling ratio and contact time at $\mathrm{pH} 7.5$, (c) $\mathrm{pH}$ and contact time at filling ratio $60 \%$

BOD removal efficiency is most extreme when $\mathrm{pH}$ in the range 68 , time in the range $2-2.2$ days in addition to filling ratio in the range $60-70 \%$. This is because that azoarcus bacteria has optimal development in the $\mathrm{pH}$ range 7-8. As time increases BOD removal effectiveness increases and $80 \%$ removal is seen at 2 days and after that slight lessening in efficiency on account of bacterial demise because of the absence of feed which expands the biological load. BOD removal efficiency increases when filling ratio is in the range $40-70 \%$ and the optimal value is discovered when filling ratio is in the range $60-70 \%$. When filling ratio is expanded over $70 \%$, BOD removal efficiency decreases because of the absence of appropriate mixing of carriers within the reactor.

\subsection{Optimum Conditions of MBBR}

The optimization plot for COD and BOD removal appears in figure 5. The efficiency of MBBR process is maximum at a $\mathrm{pH}$ of 7 and for a filling ratio of $62 \%$ after a contact time of 2.4 days. At these conditions, BOD evacuation of $68.9 \%$ and COD expulsion of $80 \%$ was acquired for the textile wastewater.

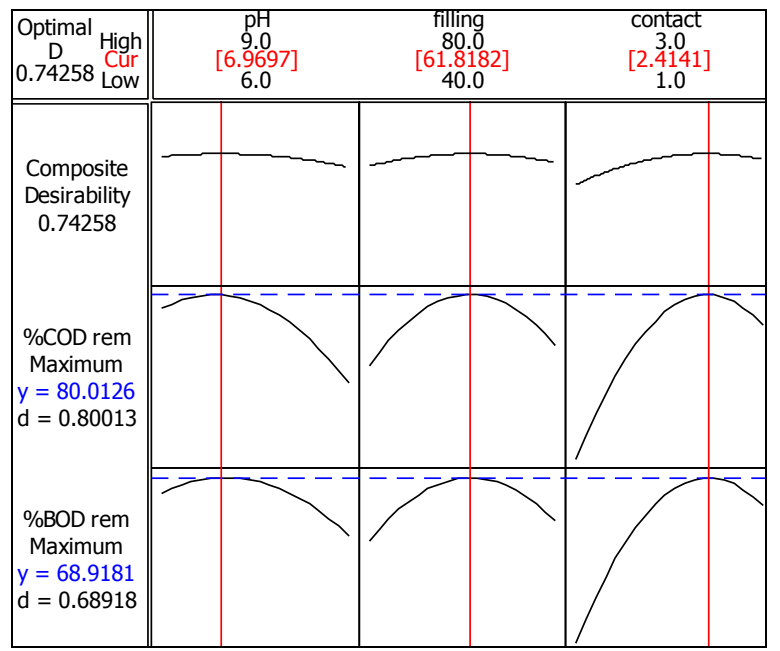

Fig.5: Optimization plots for BOD and COD removal

\subsection{Effect of Magnetic Field on MBBR Treatment}

The utilization of magnetic field to the wastewater under MBBR treatment demonstrates a slight increment in COD removal effectiveness. The reactor under magnetic field accomplished a COD removal efficiency of $87.4 \%$ while the reactor without magnetic field had a higher efficiency of $80 \%$.

\subsubsection{Effect of Field Exposure Time}

The influence of field exposure time on COD removal at optimized states of MBBR under a magnetic field of $5 \mathrm{mT}$ appears in figure 6 . The COD removal increases as the exposure time in- 
creases and it might be because of the expansion in ionization rate took after by mutual fascination and settlement of particles. The most extreme removal is attained at an exposure time of $12 \mathrm{hrs}$.

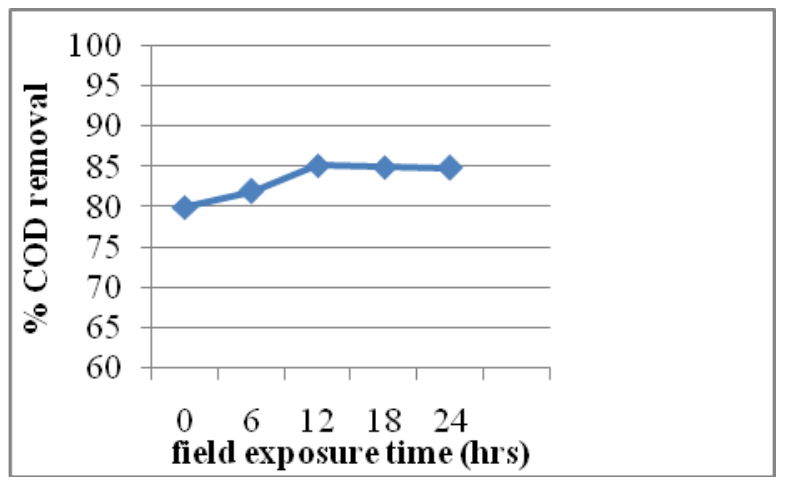

Fig.6: Effect of field exposure time(at $\mathrm{pH}=7, \mathrm{FR}=62 \%$, contact time $=2.4$ days,field intensity $=5 \mathrm{mT}$ )

\subsubsection{Effect of Magnetic Intensity}

The COD removal acquired at different magnetic field intensities at optimized states of MBBR after an exposure time of 12 hrsappears in figure 7. At first, as the magnetic field strengthens COD removal likewise increases. The organic molecules in effluent adsorb energy when it passed through the magnetic field. Some energy enhanced molecules were then induced to an excited state which increased the degradation of organic matter[11]. The greatest COD removal and BOD removal was attained at a power of $12 \mathrm{mT}$ individually.

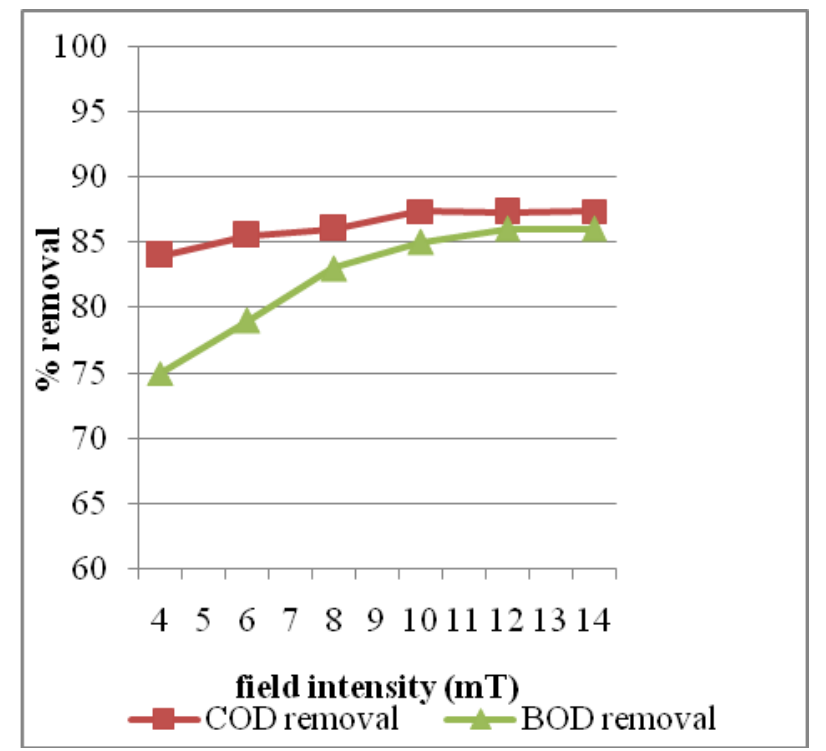

Fig.7: Effect of magnetic intensity (at $\mathrm{pH}=7, \mathrm{FR}=62 \%$, contact time $=2.4$ days, field exposure time $=12 \mathrm{hrs}$ )

\section{Conclusion}

The treatment of pre-treated textile wastewater by Moving Bed Bio film Reactor was assessed through this work. The response enhanced for COD and BOD removal and MBBR process demonstrates most extreme efficiency at $\mathrm{pH} 7$, filling ratio $62 \%$ and a contact time 2.4 days. Under these conditions, $68.9 \%$ BOD removal and $80 \%$ COD removal are attained. The treated wastewater can be utilized for irrigation purpose. By the influence of magnetic field, the efficiency of the MBBR is additionally improved. This modification results $87.4 \%$ COD removal and $86 \%$ BOD removal at $12 \mathrm{mT}$ magnetic field intensity and $12 \mathrm{hr}$ exposure time. The treated wastewater can either be released to surface water bodies or into irrigation water since it meets the benchmarks of Environmental Protection govern, 1986.

\section{Acknowledgement}

First and foremost we praise and thank the almighty for being with us throughout the research work. We express our sincere gratitude to the Principal, Govt. Engineering College Trichur for giving permission to do the research work. We extend our thanks to Environmental Engineering Laboratory staff for their constant support and cooperation.

\section{References}

[1] DebabrataMazumder(2011), "Process evaluation and treatability study of wastewater in a textile dyeing industry",International Journal Of Energy And Environment, Volume 2, Issue 6, Pp.10531066

[2] Jin X, Liu G., Xu Z., Yao W., (2007), "Decolorization of a dye industry effluent by AspergillusfumigatusXC6" Applications of Microbiology\&Biotechnology,vol-74, pp-239-243.

[3] Ramesh Babu R., Parande A.K. and Raghu S. (2007), "Textile technology: Cotton Textile Processing:Waste Generation and Effluent Treatment", Journal of Cotton Science, Vol.2,2007,pp.141-153.

[4] Muhammad Saqib Nawaz and Muhammad Ahsan(2014), "Comparison of physico-chemical,advanced oxidation and biological techniques for the textile wastewater treatment", Alexandria Engineering Journal, vol-53, pp-717-722

[5] Kalyani D.C, Patil P.S, Jadhav J.P, GovindwarS.P(2008), "Biodegradation of reactive textile dye red BLI by an isolated bacterium Pseudomonas sp.”,BioresourceTechnology, vol-99, pp-4635-4641.

[6] Jonstrup M., Punzi M., Mattiasson B (2011), "Comparison of anaerobic pre-treatment and aerobic post-treatment coupled to photoFenton oxidation for degradation of azo dyes", Journal of Photochemistry and Photobiology A: Chemistry, Vol-224, pp 55-61.

[7] Metcalf \& Eddy Inc., "Wastewater Engineering : Treatment, Disposal and Reuse", Tata Mc. Graw Hill Publishing Company, New Delhi, 4th edition, 2003.

[8] MajidKermani, BijanBina, HosseinMovahedian, Mohammad Mehdi Amin, MahnazNikaeen (2009), "Biological phosphorus and nitrogen removal from wastewater using moving bed biofilm process", Iranian Journal of Biotechnology, Vol. 7, pp-67-73.

[9] Asad, S., Amoozegar, M. A., Pourbabaee, A. A., Sarbolouki, M. N., Dastgheib, S. M. M. (2007), "Decolorization of textile azo dyes by newly isolated halophilic and halotolerant bacteria", Bioresource Technology, vol-98, pp-2082-2088.

[10] Kariminiaae-Hamedaani, H., Sakurai, A., Sakakibara, M. (2007), "Decolorization of synthetic dyes by a new manganese peroxidaseproducing white rot fungus" Dyes. Pigments.,vol-72, pp-157-162.

[11] NurSyamimiZaidi , Johan Sohaili, KhalidaMuda\& Mika Sillanpa(2014), "Magnetic field application and its potential in water and wastewater treatment systems", Separation \& Purification Re views vol-43, pp-206-240

[12] M. SrinivasaRaoand OmprakashSahu(2013), "Study of Electromagnetic Waves on Industrial Waste Water",Physics and Materials Chemistry, Vol.-1, pp 34-40.

[13] AgnieszkaTomska, Lidia Wolny (2008), "Enhancement of biological wastewater treatment by magnetic field exposure", Desalination, vol-222, pp-368-373.

[14] H. Yavuz and S.S. Çelebi (2000), "Effects of magnetic field on activity of activated sludge in wastewater treatment", Enzyme Microbiology, vol-26, pp-22-27.

[15] Bo Liua, BaoyuGao, Xing Xu, Wei Hong, QinyanYue, Yan Wang, Ying Sub (2011), "The combined use of magnetic field and ironbased complex in advancedtreatment of pulp and paper wastewater", Chemical Engineering Journal, vol-178, pp-232-238.

[16] Gordon McKay, RafieRushdy Mohammed, Mohammad Reza Ketabchi (2014), "Combined magnetic field and adsorption process for treatment of biologically treated palm oil mill effluent (POME)",Chemical Engineering Journal, vol-243, pp-31-42.

[17] Ali Yadollahpur,SamanehRashidi, ZohreGhotbeddin,MostafaJalilifar and ZohrehRezaee (2014), "Electromagnetic fields for the Treatment of Wastewater: A Review of Applications and Future Opportunities", Jr. of pure and applied microbiology,Vol8(5),pp-3711-3719.

[18] M.Kermani,B.Bina,H.Movahedian,M.M.Amin\&M.Nikaein(2008), "Application of Moving Bed Biofilm Process for Biological Organics \& Nutrients Removal from Municipal Wastewater", American Jr. Of Envl. Sciences, 4(6), pp-675-682. 
[19] M.Makowska,M.Spychala,R.Blazejewski(2009),"Treatment of eptic Tank Eflluent in Moving Bed Biological Reactors with Intermittent Aeration", Polish Jr. Of Envl. Studies, Vol.18,No.6, pp-10511057.

[20] RajeshwariSivaraj, C.AgnesMariyaDorthy\& R.Venckatesh (2011) "Isolation, Characterization \& Growth Kinetics of Bacteria Metabolizing Textile Effluent", Jr. of Bioscience Tech. ,Vol.2(4), pp-324330.

[21] OgunjobiAdeniyiAdewale, OyinloyeIyadunniAdesola\&Sanuth Hassan Adeyimi (2012), "Bioremediation of Effluent from Local Textile Industry using Bacillus licheniformis", Newyork Scie. $J r ., 5(12)$, pp-29-33.

[22] Andre BD, Fransisco JC \&JuleBL(2007), "Review Paper on current technologies for decolorization of textile effluent" ,Colourage,(40), pp-35-38.

[23] Yang Qiqi, He Quang\&HushamT.Ibrahim(2012), "Review on Moving Bed Biofilm Processes", Pak. Jr. Of Nutrition ,11(9), pp706-713.

[24] Borkar R.P., Gulhane M.L. \&Kotangale A.J.(2013), "Moving Bed Biofilm Reactor- A new Perspective in wastewater treatment" , Jr Of Envl. Scie., Toxicology \& Food Technology ,vol.6, Issue 6, pp$15-21$.

[25] Mohammed A.AbdulMajeed, HisharoHmeedAlwan, Mohammed InamBaki, FauadR.Abtan, Hussein Irzooqi Sultan(2012), "Wastewater Treatment in Baghdad city using MBBR", Engg. \& Tech. Jr., Vol.30,No.9,pp-1550-1561.

[26] Adriana Maria Lotito, Marco De Sanctis, Claudio Di Iaconi, Giovanni Bergna(2014), “Textile wastewater treatment: Aerobic granular sludge vs activated sludge systems", Water Research ,54, Pp337-346.

[27] E.HosseiniKoupaie, M.R.AlaviMoghaddam, S.H.Hashemi(2011), "Post-treatment of anaerobically degraded azodye Acid Red 18 using aerobic moving bed biofilm processes- Enhanced removal of aromatic amines", Jr. Of Hazardous materials, 195, pp-147-154.

[28] Arun Prasad \&KokatiVenkataBhaskaraRao(2011), "Physicochemical Analysis of textile effluent \&decolorization of textile azodye by Bacillus endo-phyticus strain VITABR 13", The IIOAB $J r$.vol.2,Issue2,pp-55-62.

[29] Carmen S.D.Rodrigues, Luis M.Madeira, RuiA.R.Boaventura(2014), "Synthetic textile dyeing wastewater treatment by integration of advanced oxidation \& Biological processes- Performance analysis with costs reduction", Jr. Of Envtl. Chemical Engg.,pp-1027-1039.

[30] Mariana Neamtu,AyferYediler, IlieSiminiceanu, Antonius Kettrup(2003), "Oxidation of Commercial reactive azodye aqueous solutions by the photofenton\&Fenton-like processes", Jr. of Photochemistry \& Photobiology. A: Chemistry, 16,.pp-87-93.

[31] Oliveira R.,AlmediaF.,Santos L. \& Madeira M.(2006), "Experimental Design of 2,4-Dichlorophenol Oxidation by Fenton's Reaction", Jr. of Environmental Engg. \& Management, Vol.45, No.4 pp-1266-1276. 